\title{
The Good, the Bad and the Rational: Desirable and Undesirable Migration to Cuba and Mexico (1907-1909)
}

\section{Mieke Neyens}

From 1814 to 1905 , Sweden and Norway were two sovereign states under one king and with a common foreign service. In 1905, Norway unilaterally established its own corps of consuls - a crucial factor in dissolving the Swedish-Norwegian union. Thus, in an important sense, it was ships - or more precisely, the wish to appoint the country's "own" consuls for Norwegian ships - that made Norway move. The young independent nation decided in 1907 to sponsor its first own transatlantic line, the Norway Mexico Gulf Line, whose owner, Gottfred Mauritz Bryde, understood that maritime events are not just ships but also stories about what these ships do. So he put the well-known writer Peter Lykke-Seest on his very first vessel to Cuba and Mexico. In his accounts on travel, trade, and migration, published in Norwegian newspapers and then collected in an English-language book, Lykke-Seest inscribed himself into the logic of the Norwegian - and Mexican - elites. The texts translated existing discourses on migration and international business into tangible observations. In this chapter, I will study how Lykke-Seest presents Norwegian presence in Cuba and Mexico and how his depictions draw on contemporary conceptions of "preferred" and "undesirable" migrants in both countries. It is hardly schematizing to say that for Lykke-Seest the Norwegian farmers in Cuba were the bad: they meant failure and poverty, an example not to follow. The colony of ship captains and businessmen in Veracruz represented the good: they meant money, success, and the preservation of Norwegian traditions. And in Lykke-Seest's last writings of Mexico, Porfirianism had become the word for the rational, the modern: businessmen, trade agents, and even farmers should seize the opportunities the country had to offer. Through the Norway Mexico Gulf Line, the rich virgin soil of Mexico had to be turned into a newly independent nation's goldmine, sooner rather than later. Yes, ships were meant to move Norway, or better, its money and the "best" of its people.

\section{Agents of Norwegian Trade: Bryde and Lykke-Seest}

Peter Lykke-Seest was not just any travel writer reporting on an exotic trip. He traveled with the first vessel of a state-sponsored shipping line, on the invitation

(C) KONINKLIJKE BRILL NV, LEIDEN, 2016 | DOI 10.1163/9789004307391_006 
and at the expense of its owner, Gottfred M. Bryde; in 1909 the shipowner would also finance the translation and publication of the newspaper "travel letters" as a book. ${ }^{1}$ Moreover, Lykke-Seest acknowledged Bryde's contribution to the content of the accounts: "My thanks are due to the shipowner, G.M. Bryde, for the mercantile information with which he has supplied me," we read in the preface. Lykke-Seest was a travel writer on a clear mission: ${ }^{2}$ promoting Norwegian export through the Norway Mexico Gulf Line, in the book systematically referred to as "our direct line of steamers."3

The Norway Mexico Gulf Line was Norway's first "own" transatlantic shipping line. Of course, the country had been connected to the Americas before. A great number of cargo vessels exported cod and other Norwegian products, and sailors, businessmen, emigrants, and adventurers crossed the ocean on foreign passenger lines that called at Norwegian ports (e.g., the Danish Thingvalla line) and on occasional emigrant ships under Norwegian flag. ${ }^{4}$ Yet no Norwegian company established a regular and direct transatlantic route until 1907.5 The fact that such a company was founded then with state funding has to be understood against the backdrop of events leading to Norway's independence from Sweden only two years before.

Indeed, one of the main factors contributing to the dissolution of the Swedish-Norwegian union - which in 1814 had established the two nations as sovereign states under one king and with a common foreign service - had been a longstanding difference regarding the organization of the consular

1 Peter Lykke-Seest, Mexico Havana Galveston \& Galveston: A Voyage with the First Steamer of the Norway Mexico Gulf Line with Illustrations and Trade Statistics (Kristiania: Cammermeyer, 1909). This chapter focuses on the accounts of the Latin American countries on the Norway Mexico Gulf Line route, that is, Cuba and Mexico. My analysis is based on the existing English translation of the accounts. In the quotations, I will retain the accounts' punctuation, grammar and spelling (including proper names, e.g. Christiania, Vera Cruz).

2 On the close relationship between journalism, travel writing, and imperialism, see, e.g., Edward Said Orientalism (New York: Random House, 1978), Mary Louise Pratt, Imperial Eyes: Travel Writing and Transculturation (London, New York: Routledge, 1992), David Spurr, The Rhetoric of Empire:ColonialDiscourse inJournalism, Travel Writing and ImperialAdministration (Durham: Duke University Press, 1993).

3 Lykke-Seest, Mexico Havana, Preface, 36, 134, 142, 160.

4 Ingrid Semmingsen, Utvandringen fra Norge 1865-1915 (Oslo: Aschehoug, 1950), 103-105.

5 In the 1870 s an unsuccessful attempt had been made to establish a direct steamship passenger line between Norway and the United States, but this company (Det Norsk-Amerikanske Dampskibselskabet) had lasted only a few years. On the topic, see Dag Bakka Jr., Linjer rundt jorden: historien om norsk linjefart (Bergen: Seagull, 2008), 10; Odd S. Lovoll, “For People Who 
service. ${ }^{6}$ If Norway had sought to obtain more control in matters of foreign politics from the very creation of this union, gradually the debate shifted from political to economic questions. As Norwegian shipping and trade took an upturn in the $185 \mathrm{os}$, the country's leading businessmen and shipowners began to demand that their overseas interests be better served. They complained that many Swedish consuls had little experience in the shipping business, and that consulates were not located where most needed. They expressed the need for a more commercially oriented consular service, that is, for more consulates located in ports Norwegian cargo ships called at. In the early 189 os, their demands were picked up by Norwegian politicians, particularly by the Liberal Party (Venstre), where many called for a Norwegian consular service independent from the Swedish Foreign Affairs Ministry. For the Swedes, however, this was a no go. Several committees and consultation rounds notwithstanding, the matter remained unsolved, even when in 1903 a joint Swedish-Norwegian committee recommended that both countries had their own consular service, for Norwegians and Swedes had different views on how exactly these national services should relate to the union's Minister of Foreign Affairs. Negotiations stranded, and in 1905, the new Norwegian government led by shipowner Christian Michelsen was determined to finally settle the affair, unilaterally if needed. In May of that year, the Norwegian parliament passed a law to establish a Norwegian corps of consuls. When King Oscar II of Sweden refused to sign the law, events followed in quick succession: Michelsen's government resigned, the king declared himself unable to form a new government, and the Norwegian parliament took this act as his factual resignation as king of Norway, announcing June 7 that the SwedishNorwegian union was dissolved. Norway's independence was thus a fact, and the organization of its overseas commercial activities was high on the national agenda.

This is when Gottfred Mauritz Bryde (1865-1939) stepped in. The son of a successful shipowner and businessman from the Vestfold region, Bryde began his career sailing a Norwegian cargo ship in the Mexican Gulf in the late 189os. In 1900 he settled down in Kristiania (Oslo) and established himself as a ship

Are Not in a Hurry': The Danish Thingvalla Line and the Transportation of Scandinavian Emigrants," Journal of American Ethnic History 13(1) (1993): 48-67.

6 On the topic, see e.g. Charlotte W. Syversen, "Konsulatsaken og unionsoppløsningen i 1905," in Årbok, Norsk Sjøfartsmuseum (Oslo: Museet, 2005), 95-100; Espen Storli, "Hva ville egentlig Venstre med konsulatsaken?," Historisk tidsskrift 86(02) (2007), 226-47; Iver Neumann and Halvard Leira, Konsulatsaken og rederne (Oslo: Rederiforbund, 2005). 
broker for cargo transport between Havana, Galveston, and New Orleans. ${ }^{7}$ Competition with American lines was fierce, and Bryde began to make plans for a regular line between Norway and the Mexican Gulf ports he knew well by then. In 1907, after being turned down by his country's Ministry of Commerce, Shipping, and Industry, he sought state funding directly through the parliament. The advisory committee that examined the proposal concluded that Norwegian export was likely to benefit from a regular transatlantic line and recommended state funding. ${ }^{8}$ Bryde's proposal and the committee's report were heavily debated in the parliamentary meetings of June $29,1907 .{ }^{9}$ Norway risked falling behind on the worldwide trade market, proponents argued, as many other countries already had their "own" regular lines. Without a shipping line of our own, Member of Parliament Sigvald Bergesen (a shipowner himself, as many others in the parliament) admonished, "we are bound to become what we do not want to be, a commercial province of our neighboring countries."10 Some representatives objected that the planned route along Eastern and Southern Norway would not serve the needs of the cod exporting cities on the western coast, but Bryde got what he had applied for: a three hundred thousand kroner subsidy over three years to establish the Norway Mexico Gulf Line.

\section{Lykke-Seest's Writings: Travel, Trade, and Migration}

Less than three months later, on September 15, 1907, the first vessel of the new shipping line, the SS Kristiania, left the Norwegian capital of the same name. The ship was fully loaded and also carried ten passengers, including writer Peter Lykke-Seest and his wife Lila. In his younger years, Lykke-Seest's interests had lain in commerce - as a student, a teacher, and founder of a private school

$7 \quad$ Bakka, Linjer, 122.

8 Stortingsforhandlinger, Storting 1906/1907, Tema: Sjøfart, Tillæg 2 til indst. S. IV.: Indstilling fra veikomiteen angaaende andragende fra skibsreder G.M. Bryde om statsbidrag til en dampskibsrute Norge-Cuba-Mexiko og de amerikanske sydstater, accessed February 12, 2014, https://www.stortinget.no/no/Saker-og-publikasjoner/Stortingsforhandlinger/ Lesevisning $/$ ?p=1906-07\&paid=6\&wid=a\&psid=DIVL1751\&pgid=a_0647\&vt=a\&did=D IVL1759.

9 Stortingsforhandlinger, Storting 1906/1907, Tema: Sjøfart, Stortingstidende, beh. S.tid. (7 d.): 3667-3703, accessed February 12, 2014, https://www.stortinget.no/no/Saker-og -publikasjoner/Stortingsforhandlinger/Lesevisning/?p=1906-07\&paid=7\&wid=a\&psid =DIVL735\&pgid=b_1519. Hereafter referred to as Stortingstidende. 
of commerce - but since the late 1890 s he had dedicated himself to writing. He was a prolific and all-round author, and by 1907 he had published four novels (including the bestseller Livets slump [Life's Fortunes] in 1900), ${ }^{11}$ a poetry collection, a children's book, and two comedies. He was a public figure in his time, listed in the first edition of the Handbook of Contemporary Norwegian Men and Women in 1912. ${ }^{12}$ When he crossed the Atlantic with Bryde's first ship, Lykke-Seest was to engage in yet another genre - travel writing. He combined light-hearted impressions of the places he visited and the people he met, with more impersonal accounts of Cuba's and Mexico's history, society, and culture. The book also offered trade statistics and market analysis, "good" and "bad" examples of foreign undertakings in Mexico, and lists of possible Norwegian export products and profitable investments. It is this dual focus on travel and trade that is highlighted in the book's paratexts, including the author's preface, the front cover and title page (see figure 5.1).

The book's self-presentation notwithstanding, migration is a central topic in the accounts too, as the author describes and evaluates the living and working conditions of a number of countrymen in Cuba and Mexico, and comments at length on job opportunities for Norwegians in these countries, especially in Mexico. This was, indeed, an era when thousands of Norwegians left the country in search for a better life, mostly in the United States. Emigration was an issue in Norway: people everywhere spoke of America, newspapers wrote of it, and letters told stories of success and failure. Meanwhile, Norwegian authorities had abandoned their laissez-faire stance from the 186os and had returned to the predominantly negative attitude that had accompanied emigration from its very beginning. From the 188 os onwards, emigration was again considered a problem, and politicians in Norway, as elsewhere in Europe, took measures to reduce the number of emigrants and to encourage those abroad to come home. ${ }^{13}$ Lykke-Seest's writings took part in this national debate on the consequences of emigration for society. We will nevertheless see that his book

11 Sverre Tusvik, "Bestseljarar 1900-1993. Tåketale med opplagstal," in Bestseljarar, ed. Sverre Tusvik (Oslo: Noregs Forskningsråd, 1994), 94.

12 Chr. Brinchmann, Anders Daae, and K.V. Hammer, Hvem er hvem? Haandbok over samtidige norske meend og kvinder (Kristiania: Aschehoug,1912), 168-69.

13 See Semmingsen, Utvandringen fra Norge, 405-44; Nils O. Østrem, "Myten om Amerika: ei drøfting av 'Amerika-forteljinga' og '-myten' i norsk migrasjonshistorie: vitskapsteoretisk essay," in Migrasjon som kultur: artikkelsamling, eds. Dan D. Daatland and Hans E. Aarek (Stavanger: Migrasjonsprosjektet i Rogaland i samarbeid med Rogaland forl., 2003), 44; Nils O. Østrem, Norsk utvandringshistorie (Oslo: Samlaget, 2006), 9-11, 38-39. 
does not speak with one voice; it relates to different, partially overlapping, discourses on emigration and immigration, and includes accordant representations of "undesired" and "preferred" emigrants and immigrants. ${ }^{14}$

\section{The Undesirable Emigration of Norway's "Youngest Sons"}

Lykke-Seest's accounts of the transatlantic crossing and his first encounter with "the Tropics" recollect, in the first place, the traveler's impressions and daily experiences. They exude his longing for the exotic, the authentic, and the natural. Boarding on the Kristiania, Lykke-Seest found himself "rejoicing in the thought of getting the Christiania smell thoroughly aired out, for [he] was simply sick and tired of the whole town." ${ }^{15}$ Happy to find harmony and rest on the "mighty Atlantic," he surrenders to poetic musing. "Oh, beautiful Graziosa!" he exclaims, for instance, when passing the Azores islands:

The emerald of the Azores, wonderful dream of Atlanta! Thy towns, white as a swan's breast, lie basking in the sun, guarded from the world's temptations by the mighty ocean and by the Ave Marias of the Black Friars. In thy dim olive groves, the lips of young lovers meet in passionate kisses; and beneath thy gold-laden orange trees they wander hand in hand in mute happiness. ${ }^{16}$

In a similar vein, the depictions of Havana, Veracruz, and Mexico City tell of tropical nature and volcanoes, of crowded market places and colonial churches, of sensual women, of "Indians," "negroes," and "mestizos." In addition, the travel writer engages with contemporary debates on massive emigration. In one of the accounts of the Atlantic, for example, he describes a big emigrant steamer he observes from the deck of the Kristiania:

[The ship] was full of fortune-seeking emigrants, who waved their handkerchiefs and shouted Hurrah. They were packed together like sheep in a pen, many hundreds of men, women and children, fore and aft, while the

\footnotetext{
14 I understand "discourse" as conceived by Michel Foucault in L'archéologie du pouvoir, that is, as the body of knowledge and imagery that regulates what people think, say feel, and behave. Discourses are historically and culturally specific, and they usually reflect and strengthen existing patterns of power. See Michel Foucault (1969) L'archéologie du pouvoir (Paris: Gallimard).

15 Lykke-Seest, Mexico Havana,7-8.

16 Lykke-Seest, Mexico Havana, 8.
} 


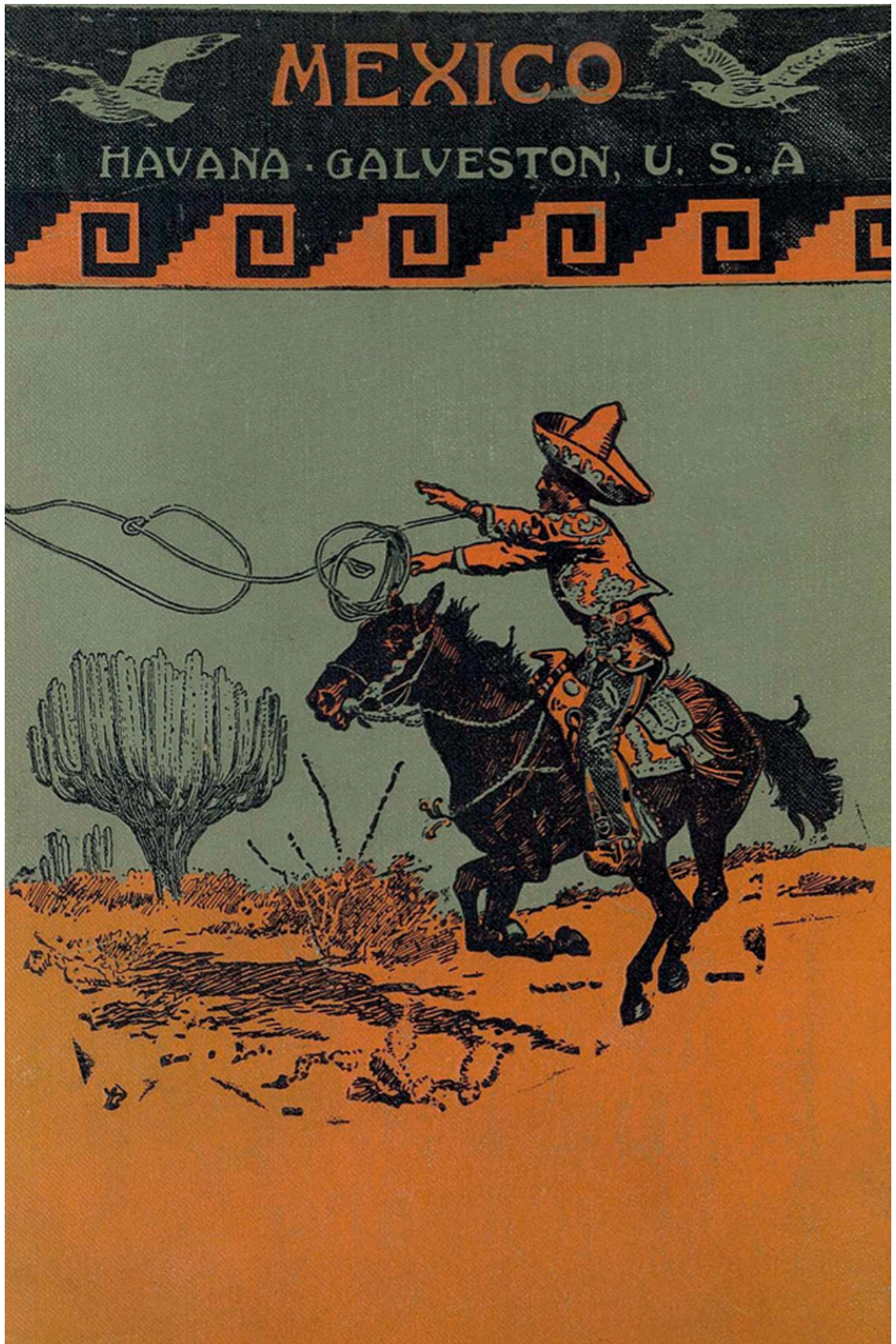




\section{MEXICO \\ HAVANA \& GALVESTON}

A VOYAGE WITH THE FIRST STEAMER OF THE NORWAY MEXICO GULF LINE"

WITH ILLUSTRATIONS AND

TRADE STATISTICS

\&
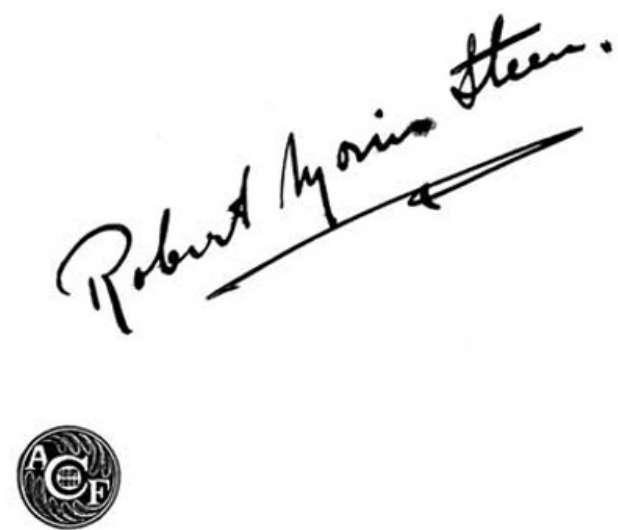

KRISTIANIA

ALB. CAMMERMEYERS FORLAG

FIGURE 5.1 Book cover and title page of Lykke-Seest's book (19o9) 
first-class passengers reclined in their deck-chairs upon the promenade deck. The emigrants looked like southerners - Italians, Portuguese, Poles, Hungarians and Jews, bound for Brazil and the Argentine Republic, to seek, in the great forests and pampas, for the golden bird that is said to dwell there, and may easily be caught. Oh, how little they know! ${ }^{17}$

The emigrants Lykke-Seest portrays in this passage are mostly poor families the people traveling in first class are not to be counted among them, they are "passengers," located on a different deck. The emigrants appear to come from Southern Europe and are hoping to get a piece of land in South America and become rich farmers. In Lykke-Seest's eyes, they are naïve to believe so, as their dreams of easy money or "golden birds," as he calls it, will most probably not to come true. ${ }^{18}$ Moreover, these crowds of emigrants leaving for America are a loss for Europe, we read:

Week after week, thousands of young fortune-seekers disperse in all directions across the boundless plains - week after week, month after month, year after year, the strength and youth of Europe. ${ }^{19}$

Here Lykke-Seest takes quite a negative stance on emigration, reproducing Norwegian authorities' official standpoint: leaving one's country behind is problematic both on a personal level, as it is likely to lead to disappointment, and on a national level, as it causes the home country to lose its most talented citizens.

We will now see that the author repeats this unfavorable representation of emigrants as naïve farmers, bound to be disappointed, in other travel letters, most clearly in the one devoted to a Norwegian plantation project in Cuba. At the same time, his depictions of the members of the so-called Norwegian colony in Veracruz seem to favor a different kind of emigration - although Lykke-Seest is careful never to use the term "emigration" in this second context.

As for the Norwegians in Cuba, Lykke-Seest portrays them as an example not to follow. He develops his overtly anti-emigration stance in one travel letter

\footnotetext{
17 Lykke-Seest, Mexico Havana, 11.

18 The image of the "golden bird" refers to a popular Norwegian folk tale and is repeated throughout Lykke-Seest's book. I will return to this tale later in the analysis.

19 Lykke-Seest, Mexico Havana, 11.
} 
from 1908, translated in the book as "Emigration to Cuba." This is the only time the author explicitly frames Norwegian presence in the region as "emigration" we will see that he most often avoids referring to Norwegians abroad as "emigrants." "The emigration of Norwegian farmers to Cuba is a fantastic idea," the account sets off, "and with the weakness we Norwegians have for the fantastical, the idea began to haunt a good many minds. I must say at once, that the emigration of Norwegian farmers to Cuba is a very poor joke." ${ }^{20}$ Lykke-Seest explicitly distances himself from the "fairy tale" stories Norwegian newspapers had written about "a man from the North" who had started a plantation in Cuba. The English translation does not mention any details about this "man from the North," but for a Norwegian audience it was clear that the author referred to polar explorer and national hero Otto Sverdrup and his much commented colonization project in the Baracoa region in eastern Cuba. ${ }^{21}$ The "man from the North" was soon followed to Cuba by other "possessed" fortuneseekers, Lykke-Seest ironically comments:

$[\mathrm{H}] \mathrm{e}$ happened to think of Cuba, and there he got land somewhere in the east in a narrow valley, to which there was neither road nor path, only a partially navigable river, up which he had to punt himself in a flat-bottomed boat. This fantastic purchase of land was written about in the newspapers, and instantly some persons were possessed with the idea. It appealed to the "youngest son" nature in our people. Their golden bird was to be found there, there was a fortune to be gained there in a short time; this was a thing to take part in. To Cuba! How mad the whole thing is! $!^{22}$

For the second time, Lykke-Seest refers to the Norwegian folk tale Gullfuglen (The golden bird). ${ }^{23}$ This is one of many tales about the youngest and most adventurous of three brothers, often called Espen Askeladd. Scorned and

20 Lykke-Seest, Mexico Havana, 40.

21 The original travel letter from 1908, published in the Norwegian paper Fri Presse, did name Sverdrup. The tone of this letter was even more negative than that of its English translation. Peter Lykke-Seest, “Cubanske breve. Udvandring til Cuba," Fri Presse, March 6, 1908.

22 Lykke-Seest, Mexico Havana, 41.

23 Folk tales belonged originally to an oral tradition of storytelling. In the 1840s, Peter Chr. Asbjørnsen and Jørgen Moe published a famous four-volume collection of tales in Norway; the story of the golden bird appears in these Norske folkeeventyr (Norwegian folktales, 1841-44). 
derided by his family, he invariably triumphs in the end, without much effort, almost accidentally. In the story of the golden bird, Askeladd wanders out in the world, catches a golden bird, and ends up marrying a beautiful princess and living in a castle. In the real world, Norway produces a lot of these "youngest sons," Lykke-Seest writes, it is "in the nature of the country."24 Cuba, however, is no place for them:

Can a Norwegian farmer cultivate tropical fruits? Can a Norwegian farmer speak Spanish? How would he be able to manage the black fellows that he must of necessity have to help with the clearing and field work? What would he live on while the "grass was growing?" What would not every bit of klip-fish, every potato cost to bring up to his clearing? "Get work?" No one but the negroes and Chinese can "work" under the sun of Cuba. Any one else would succumb in the course of a few years. ${ }^{25}$

Compared to the unlucky Southern European emigrants from the earlier account, Norwegians dreaming of Cuba are depicted in an even more negative way. For Lykke-Seest, they are not just naïve dreamers, they suffer from a mental disease: they are presented as "mad," "possessed," and "haunted" by "fantastical" ideas. And even though he appears unsure about a number of things, using modifiers as "it is not known," "I believe," and "I think," Lykke-Seest seems sure enough to frame the plantation project not just as a disappointment, but as plain failure. The Norwegians in the Cuban area of Baracoa have worked hard and invested large sums in the foreign land, he writes, yet they are not making much money; floods have destroyed some of the properties; to others, roads are scarce and in bad conditions. In short, these Askeladds did not catch the golden bird and build a castle; they live an extremely tough life in an undesirable, far-off place. ${ }^{26}$ For some engineers there might be work in Cuba, the travel writer admits, but common farmers should give up the "insane" idea of migrating to Cuba, and rich capitalists would do better investing their money at home. ${ }^{27}$

24 Lykke-Seest associates "youngest sons" leaving their country with the adventurous nature of Norwegian young men. Yet the image can also be linked to the prevailing rule of primogeniture, which forced many "youngest sons" to leave Norway where available land was scarce. See Ellen Fensterseifer Woortmann in this volume.

25 Lykke-Seest, Mexico Havana, 41.

26 Lykke-Seest, Mexico Havana, 42-44.

27 Lykke-Seest, Mexico Havana, 42. 


\section{The Exemplary "Colony” of Gentlemen}

Lykke-Seest's travel letters from Veracruz, Mexico, are a different story. They do not treat emigration explicitly as a topic. Rather, they are day-to-day accounts of the writer's experiences and impressions, including his meetings with a number of fellow countrymen living in the city. Unlike the naïve fortuneseekers on the steamer and the "mad" Norwegian emigrants in Cuba, the author's countrymen in Veracruz are respectable ship captains and successful businessmen, at all times aided by a capable Norwegian consul:

We had scarcely set foot upon Mexican land, when we were welcomed in good East-Country Norwegian by a man dressed in white. This was Herr Otto Whist, who in company with two brothers and a fourth Norwegian has started an agency business in Vera Cruz in Norwegian exports. He asked us to go up with him to his office, where the whole Norwegian colony in Vera Cruz was gathered, and wished to drink a glass with us in welcome. On the way we were met by a fresh surprise. This was the Norwegian consul in Mexico City, who had come down to receive us and accompany us to the capital. He had traveled all night, and was now sitting having his boots polished, when we suddenly came upon him. ${ }^{28}$

Despite living abroad, the members of the Norwegian "colony" in Veracruz are true Norwegians, speaking a "good" type of Norwegian. They are educated "gentlemen and ladies," always dressed impeccably, the quoted passage insists; "the Norwegian colony came to escort us [Lykke-Seest and his wife] to the railway station, every one of its members in freshly starched white suits and in good spirits," ${ }^{29}$ we read in another account. Norwegians in Veracruz live comfortable lives in a modern city, have "clean" jobs in offices, and gather regularly at fancy parties where they hold traditional speeches and sing patriotic songs, celebrating Norwegian symbols, including Bryde's shipping line:

There were sixteen of us, Norwegian ladies and gentlemen, gathered round the festal board, including the excellent vice-consul for Norway. ... The whole entertainment was marked with a spirit of the outmost heartiness.

28 Lykke-Seest, Mexico Havana, 58.

29 Lykke-Seest, Mexico Havana, 68. 
It was stylish and successful, and from my acquaintance with tropical prices, I can answer for it that it was not cheap. Captain Bodom, on behalf of the Norwegian colony, wished the guests welcome, and soon after the various speakers were in full swing. Consul Larsen said some nice things about the Norwegian seaman, and called upon us to drink to the Norwegian flag. ... [The vice-consul] rose, and made a good speech in English for the new Royal House of Norway. Once more nine hurrahs, and the national anthem. After these official healths, with their accompanying patriotic enthusiasm and numerous hurrahs, there was a little pause sufficient to allow of our putting a small quantity of food into our mouths, and then Captain Nielsen rose, stroking his white beard. This time it was for Bryde's Steamship Line. Of course Bryde's health was drunk, and then "Sons of Norway" was sung; so Bryde had every reason to be satisfied. ${ }^{30}$

In short, Lykke-Seest's accounts of Veracruz show nothing but approval, even admiration, for these people and their way of living. Compared to the naïve farmers and failed plantation owners, they seem to exemplify a more desirable type of expatriates. Once more, Lykke-Seest's accounts fit the discourse of the Norwegian authorities. The country's consul and vice-consul are much praised for their work, which seems to consist mainly of assisting Norwegian shipping captains and entrepreneurs, accordingly portrayed in a highly favorable light. Men like Otto Whist in Veracruz were, indeed, the ones who could make way for Norwegian trade and business, the ones who could open the market for Norwegian products and investors.

Lykke-Seest never calls the Norwegians in Veracruz "emigrants" - a term he reserves for farmers leaving their country behind - rather he repeatedly refers to them as a "colony." A bit surprisingly, however, Lykke-Seest at no point speaks of a "colony" of Norwegians in Cuba, even if this was how they were commonly referred to in the Norwegian press - in the sense that they were a group of countrymen "colonizing land," that is, buying land in some desert place and building their farms from scratch. The following passages from newspaper comments on Sverdrup's colonization project in Baracoa illustrate this:

[Captain Sverdrup] is going to found a Norwegian plantation there. Perhaps a Norwegian colony will arise in Cuba! ... The United States will soon be full with the stream of emigrants. Also, Norwegians disappear so easily in the States, they get lost in the mass, are wiped out over the course 
of years. So what if, instead, the Norwegian emigration stream were led to Cuba, for example, if a large Norwegian colony were established there, respecting Cuban law, of course, but still in a way that the Norwegian distinctive character, the language and so on, were to be preserved over the generations? ${ }^{31}$

[Otto Sverdrup, asked to comment upon recent social unrest in Cuba, ] would neither advise nor dissuade fellow countrymen to emigrate to Cuba. All the places in his colony are taken. ${ }^{32}$

In Lykke-Seest's accounts of Veracruz, the word "colony" is used in a broader sense, meaning "community of countrymen living abroad," and it bears a number of positive connotations, one of them being loyalty to the language and traditions of the homeland, as also in the Aftenposten article. The Veracruzian colony, moreover, consists exclusively of educated, well-off, and urban individuals. It is striking that more humble Norwegians, like for instance sailors working on the ships or in the harbor, are not referred to as part of the colony in fact, the accounts do not mention them at all. By excluding farmers, sailors, and artisans from the colony, while simultaneously praising the life and work of its successful members, the text suggests that this was the new kind of emigration Norway envisioned, an emigration not seeking to colonize new land but new markets. Once more Lykke-Seest adopts the Norwegian authorities' standpoints on emigration: whereas the Cuban migratory experience is said to be a fairy tale with a bad ending, a story of the past, the Veracruzian expatriates exemplify the successful Norwegian colony of the modern times.

\section{The Immigration of Rational Farmers}

While his writings of Cuba and Veracruz had been very personal, often dayto-day accounts of his experiences and observations, in the later Mexican accounts, published from late April 1908 onwards, Lykke-Seest switches to an apparently more objective tone. He is seldom explicitly present in the text as an eyewitness, romantic daydreaming passages become rare, and the depictions become less impressionistic and more factual. Whether the author reports on the country's history, politics, or social groups, and

\footnotetext{
31 Aftenposten March 26, 1906, quoted in Helge Stenersen, Det norske Cuba-eventyret: koloniserings-ideen som spilte fallitt (Brandbu: H. Stenersen, 1999), 11-12, my translation.

32 Stavanger Aftenblad, August 1, 1907, my translation.
} 
whether he comments on the economic situation or trade statistics, he sends a clear message to his countrymen back home - a message that also fit the shipping company's commercial goals, namely, that Mexico under President Porfirio Diaz is a modern nation with a stable economy and a growing consumer market. Like other foreigners, Norwegians should seize the countless opportunities the country offers, especially now that it had a direct connection with Norway through "our own steamers." Norwegians should trade with Mexico, they should engage in all kinds of businesses in Mexico, and they should do it before it is too late, Lykke-Seest repeatedly urges his readers:

There will be room in this country for many men with foresight and capital. The Americans have long understood this, and have established themselves in many large businesses. Norwegian enterprise might also assert itself in many ways. ${ }^{33}$

It is a country with such great possibilities for the future for Norwegian enterprise too - that if we do not do something here to work up our position, we can hardly know the time of our visitation. ${ }^{34}$

Lykke-Seest provides his readers not only with a general overview of profitable sectors of the Mexican economy (like mining and fishing), he also lists the possible factories Norwegians could build there, producing glass, motor engines, and wooden houses, for example. ${ }^{35}$ Now, starting a business on the other side of the ocean most naturally involves settling down there, so it seems that the author had come to add entrepreneurs and investors to his list of "favored" expatriates.

At other times, Lykke-Seest seems to move even further away from previous negative viewpoints, as his last writings offer a clear opening for the immigration of farmers to Mexico. ${ }^{36}$ Lykke-Seest reports, indeed, that the Mexican government wants to attract European farmers to cultivate the land - the country's "uncivilized Indians" are, after all, not up to the task:

33 Lykke-Seest, Mexico Havana, 126.

34 Lykke-Seest, Mexico Havana, 141-42.

35 Lykke-Seest, Mexico Havana, 122-38.

36 Some of these Mexican accounts were not published in Fri Presse, which ceased to exist from May 30, 1908 (yet shortly reappeared in 1929-30). They might have appeared in other local newspapers - in the book's preface, Lykke-Seest mentions that his travel letters were published in a number of newspapers - but I have not been able to trace them. It is also possible these accounts (or some of them) were written specifically for the book in 1909 . 
[Mexico] is only thinly populated. There are altogether about fourteen million persons, about six million of these being half civilised, or wholly uncivilised Indians, who cultivate nothing but a little maize, potatoes and barley for their own simple requirements. Some of them move from place to place, and are a hindrance to rational agriculture. ... The Government are also turning their attention to the question of the immigration of farmers from Europe, and the time cannot be far distant when large portions of Mexico's hills and dales in the temperate zone will be open to cultivation by capable farmers. At present, however, this matter has only arrived at a preparatory stage. ${ }^{37}$

Lykke-Seest does not explicitly mention Norwegian farmers, but compared to the Cuban travel accounts, he now speaks in a surprisingly positive way of immigration and tropical agriculture. No reference here to mentally ill migrants European farmers in Mexico are portrayed as "capable" and "rational." No illusionary golden birds - Mexico offers plenty of good land, waiting for immigrants to cultivate it: "How will it be," Lykke-Seest dreams away, "when this enormous country is cultivated, when immigration begins to increase, and the rich, virgin soil comes under the plough?"38 Indeed, at times it seems that it is not the immigrants but the writer himself who now fantasizes of "golden birds," for example when he claims that "an orange grove will spring up if you only drop a pip on the ground" 39 and that large amounts of forest are just "lying useless, waiting to be turned into gold." ${ }^{40}$ No mention either of the possible difficulties of cultivating tropical fruits, learning a new language, or working in tough conditions under a burning sun. Moreover, contrary to the rather primitive Cuban plantations, agriculture in Mexico is associated with science, rationality, and modernity:

A large part of the good land in Mexico has too little water to allow of its being cultivated, but to remedy this the Government has in the meantime voted twenty-five million pesos for irrigation, while experiments are being made at various places in rational cultivation. For the encouragement of agriculture, the various states have established large, well arranged agricultural schools under capable management, and new roads to the connecting points

\footnotetext{
37 Lykke-Seest, Mexico Havana, 123.

38 Lykke-Seest, Mexico Havana, 141.

39 Lykke-Seest, Mexico Havana, 106.

40 Lykke-Seest, Mexico Havana, 122.
} 
are continually being laid. The construction of railways must also be mentioned in this context. ${ }^{41}$

Agriculture in Mexico is the agriculture of the future. And again the word "colony" appears, ${ }^{42}$ this time referring to farming projects (as the ones in Cuba), yet also clearly associated with modern types of agriculture (unlike the ones in Cuba).

So, why this turn away from the previous straightforward anti-emigration position? I will now argue that, through his readings and encounters in the Mexican capital, Lykke-Seest became acquainted with the image that the local political and economic elites presented of their country and its leader for more than thirty years by then, president Porfirio Diaz: Mexico as a country with countless opportunities for immigrants. At the same time, the later Mexican accounts bear a striking resemblance to popular contemporary English and American travelogues of the country, which are said to have popularized the image the country sought to spread of itself - an image that also fit Bryde's and Lykke-Seest's message.

Commissioned by shipowner Bryde, Lykke-Seest's travelogue inevitably promotes the shipping company's trade and business interests, particularly in Mexico. Attracting foreign investors and a skilled workforce had become the Mexican government's main strategy for stimulating the economy, and President Diaz and his ministers actively construed an image of Mexico as a modern country of unlimited opportunities for immigrants. ${ }^{43}$ Lykke-Seest lived in Mexico for more than six months, and during his stay he spoke with several state officials, even meeting with the president himself.4 ${ }^{44}$ His book happily integrates information and statistics that he reports to have received directly from the president's "departments." ${ }^{45} \mathrm{His}$ local written sources seem to have been predominantly supportive of the Us-friendly Diaz regime: his readings ${ }^{46}$ include the state-subsidized El Imparcial, the Mexican Daily Record, financed by the owner of the United States Banking Company, ${ }^{47}$ and the Mexican Herald,

\footnotetext{
41 Lykke-Seest, Mexico Havana, 124.

42 Lykke-Seest, Mexico Havana, 123.

43 Jürgen Buchenau, "Small Numbers, Great Impact: Mexico and Its Immigrants, 1821-1973," Journal of American Ethnic History 20(3) (2001), 31-35.

44 Lykke-Seest, Mexico Havana, 106-10, 119-22.

45 Lykke-Seest, Mexico Havana, 110, 138, 143.

46 Lykke-Seest, Mexico Havana, 118.

47 Schell, William, Integral Outsiders: The American Colony in Mexico City, 1876-19n1 (Denver: SR Books, 2001), 99.
} 
said to be closely intertwined with the Diaz regime, perhaps even subsidized by it. ${ }^{48}$ If, as Paul Garner points out, "dissident voices were constantly heard and opposition papers continued to publish" throughout the Porfiriato, ${ }^{49}$ LykkeSeest seems to have been either unaware of their existence or reluctant to cite them, claiming that "there is no real opposition press in Mexico."50 In short, Lykke-Seest's sources seem to have been mainly Mexican, and mainly allied to Porfirianism. The Mexican "insider's position" he had come to adopt is reflected, for example, in his using the term "immigration" in the Mexican book chapters, and not "emigration," as in his previous accounts of Cuba.

Lykke-Seest's fairly uncritical integration of a Porfirian discourse can thus be understood, in the first place, in the context of the commercial interests his sponsor had in Mexico - interests that were well served with the Porfirian message of "countless opportunities for immigrants." Yet there might be another possible explanation for the shift to a more positive image of the migration of farmers to Mexico. Bryde's correspondence - whether with his Mexican representatives and advocates, with Minister Michael Strøm Lie of the Norwegian legation in Mexico City, or others - suggests that the Norway Mexico Gulf Line actually planned to ship Norwegian farmers to Mexico. ${ }^{51}$ Well aware of the Mexican government's colonization projects, the company offered to ship emigrants at preferential rates, in exchange for a subsidy of fifty-five thousand pesos over three years. In 1912, after five years of negotiations, in which also Minister Lie and other representatives of the Norwegian government had participated, a contract between the Mexican government and the Norway Mexico Gulf Line was drawn up, specifying, among other things, that the company would ship Norwegian "colonists" and temporary wooden houses from Kristiania to Puerto Mexico and Veracruz. However, because of the Mexican Revolution, which had come to shake the country in 1910 and which would last more than a decade, the agreement was never signed. But it is not unlikely that Lykke-Seest at some point had learned of the plans of his benefactor and pragmatically opted for a less negative stance towards colonization projects in Mexico.

At the same time, Lykke-Seest might have found inspiration for his Mexican accounts in some of the many best-selling travelogues of the country, such as

48 Jerry W. Knudson, "The Mexican Herald: Outpost of Empire, 1895-1915," International Communication Gazette 63(5) (2001), 387-98.

49 Paul Garner, Porfirio Díaz (Harlow: Routledge, 2001), 123.

$50 \quad$ Lykke-Seest, Mexico Havana, 118.

$5^{1}$ Archive of the Norwegian Legation in Mexico, Department of Foreign Affairs, A2065, Loo11 HAN, nr. 0002. 
those by British-American Mrs Alec-Tweedie and American William Carson. These texts sang the praises of President Porfirio Diaz and spread the image of a modern country, welcoming foreign investment for the extraction of the natural wealth - an image Diaz and his advisors sought to spread. According to Jason Ruiz, American travel writers "played a crucial but overlooked role in popularizing the image of Mexico as an object of the cultural and economic forms of us imperialism that flourished around $1898 .{ }^{\prime 52}$ Lykke-Seest's texts seem to follow these models: he dedicates pages and pages to the glorification of President Diaz, admires the country's modern facilities, and enumerates its unlimited natural resources - and he does so in much the same words and images as his American colleagues. William E. Carson, for example, writes the following in Mexico, Wonderland of the South (1909):

Under his [Porfirio Diaz's] stern rule, the progress of Mexico has been marvellous. The old Mexican cities have suddenly become busy places, with new public buildings, fine shops, asphalted streets, electric lights, electric street-cars and other visible evidence of modern progress. ... Welcomed by the government, men with money are swarming into Mexico from all parts of the world to engage in business, particularly mining; for the mineral riches of the country, its gold, silver and copper, have not been half developed. ${ }^{53}$

Compare that description with how Lykke-Seest portrays Mexico City as a modern capital attracting enterprising men from abroad:

The old Aztec city on the table-land has now become a modern capital, with electric lighting, asphalted streets, an extensive system of electric tramways, handsome shops, beautiful parks, and broad avenues. It has about 400,00o inhabitants, and is steadily increasing. People flock to it from the United States and from all the countries of Europe; for Mexico is a country with great possibilities for the future, and as the country's natural sources of wealth are utilised more and more the city on the table-land will also increase in population and in the accessories of modern life..$^{54}$

52 Jason Ruiz, "A New Factor in American Destiny: Visions of Porfirio Díaz and the Politics of 'Logical Paternalism,', Journal of Transnational American Studies 3(2) (2011), 2.

53 William E. Carson, Mexico, Wonderland of the South (New York: The Macmillan Company, 1909), 206.

Lykke-Seest, Mexico Havana, 79. 


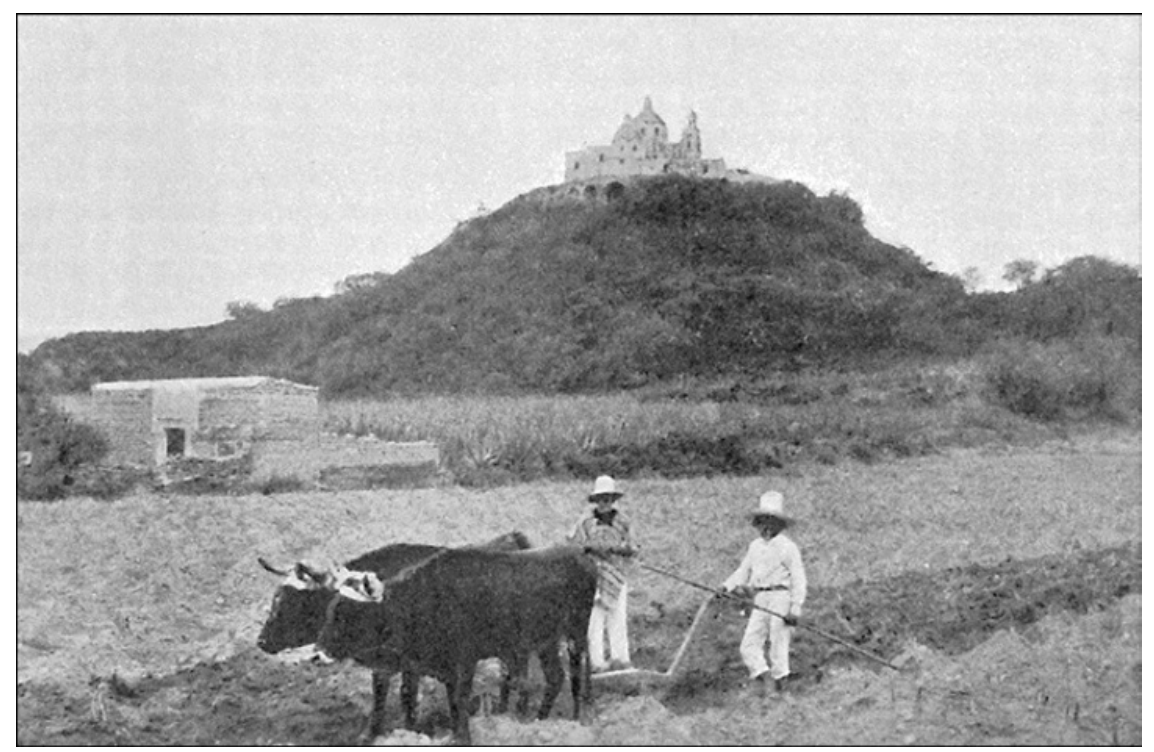

FIGURE 5.2 Cholula ${ }^{55}$

The 1909 book also includes many pictures that seem to have been popular in other travel books of Mexico, like the one portraying two farmers plowing the land against the background of the Great Pyramid of Cholula, on top of which the Spanish had built a church in the sixteenth century (figure 5.2); this same picture is used in both Carson's and Tweedie's works. Like many other travelogues of Porfirian Mexico, ${ }^{56}$ Lykke-Seest also chose a portrait of President Diaz as a frontispiece for his book (figure 5.3). For Anglo-Saxon travel writers, it was, indeed, often President Diaz himself who embodied Mexico's progress, stability, and future opportunities for foreign investment. ${ }^{57}$ Again Lykke-Seest seems to follow their example, often turning to an image of the "great statesman" Diaz "laying the lines" for present and future development, or "conducting the train or the ship" that is Mexico, ${ }^{58}$ like in the following example:

\footnotetext{
55 In Alec-Tweedie, The Maker of Modern Mexico. Porfirio Diaz (New York: John Lane, 1906), 88; Lykke-Seest Mexico Havana, 73; Carson Mexico, Wonderland, 238.

56 Ruiz, "A New Factor," 5.

57 Ruiz, "A New Factor"; Garner, Porfirio Diaz, 7-12.

$5^{8}$ Lykke-Seest, Mexico Havana, 101, 105, 122.
} 


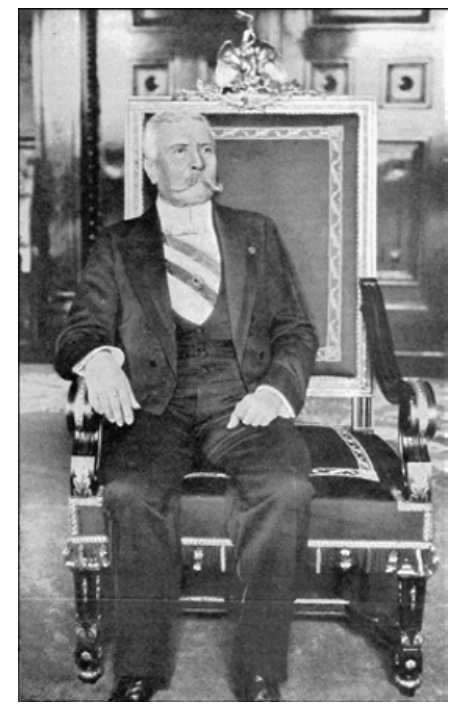

FIgURe 5.3 Porfirio Día $z^{59}$

The line has been laid, and the engine, which had left the rails, has now been rerailed, and is steaming away at a good, steady, irreproachable pace; and Porfirio Diaz himself stands by the lever. It is not as a war-hero that Porfirio Diaz will gain posthumous renown, but as a state organiser. ${ }^{60}$

This echoes the praise from other travelers, such as Mrs Alec Tweedie in her 1906 book The Maker of Modern Mexico:

Porfirio Diaz has been allowed to build up the modern State of Mexico on the lines that he himself laid out, undisturbed by the rivalries of other would-be constructors, and it will be an imperishable monument of his fame. ${ }^{61}$

Mexico, in short, had no credit. But it possessed a man [i.e., Diaz], known to the world at that time as a brilliant soldier, but who was to prove himself even greater as a statesman and administrator. ${ }^{62}$

\footnotetext{
59 In Alec-Tweedie, The Maker, 348; Lykke-Seest, Mexico Havana, frontispiece.

6o Lykke-Seest, Mexico Havana, 106.

61 Alec-Tweedie, The Maker, 337.

62 Alec-Tweedie, The Maker, 272.
} 
What makes the similarities between these writings interesting is not so much that Lykke-Seest might have actually read Carson's and Tweedie's texts and copied them - which in the case of Carson is most unlikely, as his book came out in the same year as Lykke-Seest's - but rather that Lykke-Seest seems to have inscribed himself in a tradition of travel writing that reproduced the image the Mexican government carefully crafted of the country and its leader. ${ }^{63}$

Lykke-Seest's book, however, also differs from the Anglo-Saxon tradition in that the success of future Norwegian business projects in Mexico is not taken for granted. Time is running out, Norwegians might arrive too late, the author insists. Unlike the British and American travelogues, the tone of the Norwegian book is a combination of exhortation and despair:

The thing is to take time by the forelock, to seize the chances before they vanish. There are many hands stretched out for them. Here in Mexico, the various nations are pushing in with strength, energy and capital, in order to profit as much as possible by the development of the country. And we too could assert ourselves if we can and will venture in where so many that are stronger are trying to get everything. ${ }^{64}$

An interesting detail is that Lykke-Seest also seeks to "Norwegianize" the image of Porfirio Diaz, turning once more to the image of the "youngest son", "He was a modern 'younger son' of the fairy tales, who attained his object, not when asleep, like some of the fairy tales' 'younger sons': but through fighting, exertion, and strength of will."65 Unlike the fictional youngest son who just happens to succeed in life, unlike the real-life migrating youngest sons dreaming of easy money, Porfirio Diaz embodies a "modern young son," one who all the way knew perfectly well what he was doing, one who fought and struggled and reached his goal: "He set himself a task, and he accomplished it. His indomitable will, his political wisdom, his untiring energy, were the qualities that saved Mexico from a self-consuming fire."66 If the fairy tales of emigration inevitably failed to have a happy ending in the original travel letters from 1907-8, such endings do exist in 1909 - thanks to Porfirio Diaz's efforts. For Lykke-Seest,

\footnotetext{
63 Garner, Porfirio Diaz, 2, 12.

64 Lykke-Seest, Mexico Havana, 135.

65 Lykke-Seest, Mexico Havana, 105.

66 Lykke-Seest, Mexico Havana, 105.
} 
Mexico in 1909 is a "wonderful fairy-land," 67 but one where an improved version of the Norwegian youngest son makes dreams come true.

\section{Concluding Remarks}

Lykke-Seest's texts were very much a product of their times. Partly conceived as personal impressions of a escapist journey to "the Tropics," they also engaged in contemporary debates on emigration, shipping, and trade. The depictions of the emigrant steamer and Norwegian plantations in Cuba voice Norwegian authorities' highly negative stance towards the emigration of Norwegian farmers. Furthermore, the accounts of the writer's festive stay with the Norwegian "colony" in Veracruz can be related to Norway's dispute with Sweden over having its "own" consular representation abroad and to the assumedly "natural" alliance between Norwegian consulates, shipping, and export.

Yet the texts were also very much an expression of their author's personal longings - of a late romantic travel writer on an exotic trip and an amateur market analyst on a mission, namely, promoting Norwegian trade and investment in Mexico through "our own line of steamers." Possibly inspired by a tradition of American and British travel writing of Mexico, and perhaps aware of the shipping company's plans to carry Norwegian farmers to Mexico, Lykke-Seest gradually abandoned his overt anti-emigration stance and moved towards an image of the country as a "fairy-tale land" for foreigners, wholeheartedly integrating the Porfirian discourse of a "modern Mexico for all immigrants."

Still, Norwegians did not massively move to Mexico with the Norway Mexican Gulf Line or otherwise, neither to seek new land nor to seek new markets. Steinar A. Sæther and Nils Olav Østrem have estimated that between three hundred and six hundred Norwegians migrated to the country before 1940 - a small number compared to the ten thousand or so who migrated to the whole of Latin America. ${ }^{68}$ Porfirian rhetoric notwithstanding, Mexico was by no means a fairy-tale land for immigrants: wages were low, the best lands were

67 Lykke-Seest, Mexico Havana, 106.

68 Steinar A. Sæther and Nils Olav Østrem, "Norwegian Emigration to Latin America: Numbers, Questions and Methods," in Christina Folke Ax and Nils Olav Østrem (eds.), Nordic Migration. Research Status, Perspectives and Challenges (Stamsund: Orkana Akademisk, 2011), 130-31. 
already taken, and colonization programs were scarce. ${ }^{69}$ The Mexican Revolution (1910-20), which plunged the country into chaos, did not make it more attractive to foreigners, and Norwegian presence was more than halved between 1910 and $1921 .^{70}$ As shown by Sæther in the first chapter of this book, the number of arrivals in Mexico increased again in the 1920s, while the number of resident Norwegians continued to decline, suggesting that many either returned to Norway or moved on to their next destination, for instance the nearby United States. This pattern was not unique to Norwegians in Mexico: Pablo Yankelevich points out that, in the late 1920s, less than a third of the total number of immigrants who entered Mexico each year actually settled in that country. Most considered it an antechamber to the United States, where immigration policies had become more restrictive. ${ }^{71}$

Lykke-Seest's texts do indicate that small Norwegian networks were in place in Cuba and Veracruz at the beginning of the twentieth century, and that information about job opportunities was circulating - Lykke-Seest's own stories of failure and success, for one, but also the newspaper "fantasy" stories about the plantations in Baracoa that he refers to. Still, migration from Norway to these places never really took off. In the case of Mexico, the aforementioned numbers suggest that the Mexican Revolution interfered with the endogenous dynamics that for Thomas Faist are crucial for any migration process to reach a climax. ${ }^{72}$ As for the plantation projects in Eastern Cuba, Helge Stenersen attributes their failure to exceptional climatic circumstances in 1907-9 and the lack of transportation routes from the region - a long-expected train connection with Santiago was never established, nor did steamship routes regularly call at Baracoa port. ${ }^{73}$ More than network dynamics, macro factors (political, climatic, economic) may, thus, have had an impact on the Norwegian migration stream to Mexico and Cuba at the beginning of the twentieth century.

69 Buchenau, "Small Numbers, Great Impact," 31-36; José C. Moya, "A Continent of Immigrants: Postcolonial Shifts in the Western Hemisphere," Hispanic American Historical Review 86(1) (2006), 19.

$70 \quad$ Sæther and Østrem, "Norwegian Emigration to Latin America," 130-31.

71 Pablo Yankelevich, "Mexico for the Mexicans: Immigration, National Sovereignty and the Promotion of Mestizaje," The Americas 68(3) (2012), 411-12.

72 Thomas Faist, The Volume and Dynamics of International Migration and Transnational Social Spaces (Oxford: Clarendon, 2000), 145ff. See also the introduction of this book.

73 Helge Stenersen, Det norske Cuba-eventyret. According to Stenersen, the "Norwegian Age" in the Baracoa region lasted from 1906 to 1919. During those years, altogether ninety-seven Norwegians lived for a shorter or longer period in the Baracoa district. Many left Cuba for the United States. None stayed. 
All in all, Lykke-Seest's (and Bryde's) discursive efforts to mobilize people and money from Norway to Mexico may have had a limited effect on the history of migration. Yet the texts have proven interesting: first, in that they testify to the close relation between shipping, state politics, and migration in the Norway of the early 19oos; second, in that they recollect Norway's attempts to assert its position in an increasingly globalizing market; and third, in that they reflect, support, and preserve conceptions of desirable and undesirable migrants that existed on both sides of the Atlantic. 